Michael Tengberg

Karlstads universitet

Marie Wejrum

Karlstads universitet

DOI: http://dx.doi.org/10.5617/adno.7985

\title{
Observation och återkoppling med fokus på utvecklad undervisning: Professionsutveckling med hjälp av PLATO
}

\begin{abstract}
Sammandrag
De senaste åren har stor uppmärksamhet riktats mot behovet av praktiknära, eller praktikutvecklande, forskning i skolan. Tillsammans väntas forskare och lärare utarbeta ny kunskap och vetenskapligt underbyggda metoder för höjd kvalitet och ökad måluppfyllelse. Föreliggande artikel rapporterar resultat från en kvalitativ pilotstudie tillsammans med fyra lärare i det så kallade ULF-projektet (Utbildning, Lärande, Forskning), där forskare och lärare på gemensamt initiativ prövar en modell för samarbete om utvecklad undervisningskvalitet.

Studien bygger på tidigare storskaliga observationsstudier där särskilda observationsprotokoll utformats för att identifiera kritiska aspekter av undervisningskvalitet. Syftet med studien är att pröva om observationer och videoinspelningar av undervisning följt av återkoppling till lärarna utifrån ett sådant observationsprotokoll (PLATO) kan användas för att stötta lärarnas undervisningsutveckling. Forskningsintresset riktas dels mot observationernas och återkopplingens eventuella påverkan på undervisningen eller på lärarnas tänkande om undervisningen, dels mot förutsättningarna för att underlätta och utvidga samarbetet och göra det mer långsiktigt hållbart.

Resultaten antyder att de forskningsbaserade kvalitetsdimensionerna i PLATO synliggör relevanta utvecklingsområden som lärarna drar nytta av i planering och analys av sin undervisning. Samtidigt konstateras att ett fungerande forsknings- och utvecklingssamarbete fordrar mer tid i lärarnas schema för planering och reflexion och en lokalt placerad ämneskompetent mottagarresurs som kan driva och förankra utvecklingsarbetet på huvudmannanivå. Implikationer för ett utvecklat och uppskalat samarbete diskuteras i artikeln.
\end{abstract}

Nyckelord: observation, PLATO, praktikutvecklande forskning, undervisning, återkoppling

\section{Observation and feedback for improved instruction: Professional development by PLATO}

\begin{abstract}
In recent years, increased attention has been devoted to the need for practice-based research in education. Together, teachers and researchers are expected to build new knowledge and arrive at evidence-based methods for improved quality and more
\end{abstract}


efficient learning in schools. This article reports from a pilot study in the Swedish ULF project (Utbildning, Lärande, Forskning [Education, Learning, Research]), where researchers and teachers, on joint initiative and within the context of application, try out a model of collaboration for improved instructional quality.

This research builds on previous large-scale studies where observation protocols have been used to identify critical aspects of instructional quality. The study aims to determine whether observations and video recordings of teaching followed by feedback to teachers, based on an observation protocol (PLATO), can be used to support the improvement of language arts instruction. Research interests concern both the effect caused by observation and feedback on teachers' practice and their thinking about practice, and the potentials and pitfalls for a sustained collaboration.

Findings indicate that the research-based quality criteria in PLATO pinpoint areas of development relevant for teachers' planning and analysis of instruction. At the same time, the collaboration accentuates the need of more time for planning and reflection in teachers' schedule as well as a local change agent to operate and authorize professional development at school level. Implications for an extended and large-scale collaboration are discussed.

Keywords: collaborative research, feedback, instruction, observation, PLATO

\section{Introduktion}

En rad studier från senare år indikerar att lärares undervisning är den enskilt viktigaste faktorn för elevers kunskapsutveckling i skolan, viktigare än klassrumsstorlek, socio-ekonomisk bakgrund och längden på lärares utbildning eller erfarenhet (Bryk, Sebring, Allensworth, Luppescu \& Easton, 2010; Haertel, 2013; Hattie, 2009). Dessutom visar studier att det är stor skillnad på i hur hög grad olika lärare påverkar sina elevers kunskapsutveckling (Haertel, 2013). Tillsammans med det ökade intresse för undervisningens kvalitet, som följt i spåren av sjunkande resultat för svenska elever i internationella kunskapsmätningar har den här sortens forskningsresultat ökat intresset för insatser som skulle kunna bidra till bättre undervisning. Vilka aspekter av undervisningen som, tillsammans eller var för sig, skapar bäst förutsättningar för elevers lärande, råder det emellertid mindre enighet om. Man kan naturligtvis fråga sig om det över huvud taget är möjligt att producera generellt giltiga svar på en så övergripande frågeställning. Det gör dock inte frågan i sig mindre angelägen och många försök till identifiering av så kallade framgångsfaktorer har gjorts. Till de aspekter som ofta betonas hör bland annat lärarens förmåga att tydliggöra mål för eleverna, att ge återkoppling på deras prestationer, att tillgängliggöra lärandestrategier liksom att både lyfta och utmana elevers tänkande under skolarbetet (se t ex Bell, Dobbelaer, Klette \& Visscher, 2018; Gore, Lloyd, Smith, Bowe, Ellis \& Lubans, 2017; Hattie, 2009). Detta är aspekter som brukar inkluderas i observationsinstrument för systematisk analys och/eller värdering av klassrumsundervisning. Men sådana observationsinstrument kan också användas för att bygga upp ett gemensamt språk för hur vi benämner och identifierar undervisningskvaliteter och för att ge återkoppling till 
lärare i syfte att förbättra undervisningen (Gore et al., 2017; Steinberg \& Sartain, 2015; Taylor \& Tyler, 2012). En liknande ansats prövas i den här studien.

Instrument som på basis av tidigare forskning preciserar kvalitetsfaktorer i undervisning har alltså tjänat som verktyg i handen på skolinspektörer eller rektorer som utvärderar lärare för att "granska kvaliteten" eller för att "ovanifrån” driva på kvalitetsutveckling. Walls och Nilsson (2019) har nyligen kritiserat hela idén om skolutveckling med denna farhåga som bakgrund. De menar att iverksättandet av systematisk pedagogisk utveckling kringskär lärares professionella autonomi och snarare syftar till att etablera en inre kontroll utifrån ett yttre politiskt krav om ständig förbättring och ökade resultat. Det är en motiverad farhåga, men den grundar sig i en alltför snäv syn på vilken funktion ett lokalt skolutvecklingsarbete skulle kunna fylla. Ett annat sätt att dra nytta av kvalitetsindikatorer som definierats i observationsprotokoll| skulle kunna vara att göra dem till del av lärares gemensamt självägda professionsutveckling (Colbert, Brown, Choi \& Thomas, 2008). Med självägt menas ett utvecklingsarbete som lärare själva både genomför och följer upp resultaten av, i motsats till ett förändringsarbete som går ut på att lärare följer en färdig mall där någon annan sedan ska svara på om insatsen varit verkningsfull eller inte (jfr Sparks, 2004). Att utvecklingsarbetet är självägt innebär också att etablering och kunskapsspridning i första hand sker genom att det är deltagarna själva som använder kunskapen och sprider den genom samarbete i professionella gemenskaper snarare än genom att forskare publicerar texter som lärare förväntas läsa (jfr Gibbons, Limoges, Nowotny, Schwartzman, Scott \& Trow, 1994). I en sådan användning skulle välutvecklade instrument för att synliggöra och verbalisera undervisningskvaliteter kunna bli verktyg för egenstyrd utveckling istället för att tjäna som måttstock för utvärdering och kontroll. Den här artikeln rapporterar resultat från en mindre undersökning där vi prövat om observationer av videoinspelad undervisning och återkoppling till lärare baserat på utvalda variabler från ett sådant observationsprotokoll kan användas för att stötta lärarna $\mathrm{i}$ att utveckla sin undervisning.

\section{Bakgrund}

Våren 2017 beslutade den svenska regeringen att initiera en försöksverksamhet (det så kallade ULF-projektet: Utbildning, Lärande, Forskning) i syfte att utveckla och pröva olika modeller för samverkan mellan universitet och skolhuvudmän kring praktiknära forskning (Utbildningsdepartementet, 2017). ${ }^{1}$ Satsningen på försöksverksamheten skulle, enligt regeringsbeslutet, bidra till en stärkt vetenskaplig grund i lärar- och förskollärarutbildningarna och i skolväsendet. Under en inledningsfas av försöksverksamheten initierades vid Karlstads universitet ett antal mindre pilotprojekt. Dessa utgjorde en fördjupning av redan pågående praktiknära forskningssamarbeten med skolhuvudmän och syftade till att pröva

\footnotetext{
${ }^{1}$ I det följande använder vi emellertid istället begreppet praktikutvecklande forskning, som vi menar är en mer adekvat beskrivning av forskningssamarbetets fokus (se bl a SOU 2018:19).
} 
och belysa förutsättningarna för ett utökat samarbete både på övergripande nivå mellan universitet och skolhuvudmän och på konkret projektnivå mellan forskare och förskollärare/lärare. I den här artikeln rapporterar vi resultaten från ett av dessa pilotprojekt. Vårt fokus ligger dock inte i huvudsak på samverkansstrukturerna som sådana utan på samarbetsformernas betydelse för lärarna och deras undervisning liksom på möjligheterna att använda observationsprotokoll, videoinspelningar och återkoppling som grund för ämnesdidaktisk professionsutveckling.

I det nordiska, videobaserade forskningsprojektet Linking Instruction and Student Achievement (LISA) (Klette, Blikstad-Balas \& Roe, 2017) används observationsprotokollet Protocol for Language Arts Teaching Observation (PLATO) (Grossman, Loeb, Cohen \& Wyckoff, 2013). PLATO har utvecklats med stöd i tidigare empirisk klassrumsforskning och identifierar tolv olika element av lärares undervisningspraktik som antas vara kritiska för mellan- och högstadieelevers kunskapsutveckling i motsvarande language arts (här svenskämnet). Statistiska analyser har påvisat signifikanta samband mellan de praktiker som fångas i PLATO och elevers utveckling på standardiserade tester (Cohen \& Grossman, 2016; Kane \& Staiger, 2012). Intressant nog ger PLATO-kodning högre utslag på tester som prövar mer komplexa förmågor inom language arts (Grossman, Cohen, Ronfeldt \& Brown, 2014). Tillsammans sätter variablerna i PLATO-protokollet fokus på lärares strategier för att stötta elevernas lärprocesser, de ämnesrelaterade och kognitiva utmaningar som eleverna ställs inför, klassrumsklimatet och tidsanvändningen samt på hur ämnesinnehållet representeras och presenteras i lärarens undervisning. Lektioner som spelats in kodas i 15minuterssegment och för var och en av variablerna finns detaljerade kvalitativa kriterier för kodning på en fyrgradig skala. Den första datainsamlingsomgången i LISA-studien i Sverige omfattade bland annat femtionio lektioner i svenska i årskurs sju hos femton olika lärare på sex olika skolor. Preliminära resultat indikerade att ett viktigt utvecklingsområde för svensklärarna handlade om att ge tydliga stödstrukturer för elevers lärande. Ett annat utvecklingsområde gällde att vidmakthålla en intellektuellt utmanande nivå i de uppgifter som eleverna utför liksom i klassrumsinteraktionen om texter (Tengberg, 2019). Mer specifikt synliggjorde studien att elever i många klassrum sällan undervisades explicit i strategier för att lösa mer komplexa uppgifter eller gavs konstruktiv återkoppling på sina prestationer. Det framgick också att arbetet i klassrummet i ganska liten utsträckning uppmuntrade eleverna till mer kvalificerat analytiskt och inferentiellt tänkande (ibid.).

\section{Observationsprotokoll för professionsutvecklingssyfte}

Att använda observationsprotokoll för att ge återkoppling till lärare på deras undervisning och på så vis stimulera till professionsutveckling har föreslagits och prövats i några tidigare studier. Crosson, Boston, Levison, Matsumura, Resnick, Wolf och Junker (2006) argumenterar för att instrument som ursprungligen tagits 
fram för storskaliga utvärderande syften också skulle kunna användas för att ge återkoppling till lärare på genomförd undervisning och därigenom stötta professionsutveckling. Författarna tar utgångspunkt i observationsprotokollet Instructional Quality Assessment (IQA) och understryker att de detaljerade kvalitativa deskriptorer för olika nivåer, som finns för varje delaspekt, gör det möjligt för lärare att få syn både på vad ett successivt mer avancerat sätt att exempelvis genomföra intellektuellt utvecklande textsamtal med elever innebär i praktiken och på vilka antaganden om elevers förståelseprocesser som ligger bakom kriterierna (Crosson et al., 2006, s. 4). I en studie av Allen, Pianta, Gregory, Mikami och Lun (2011) prövades ett webbaserat program för att genom insända videofilmer av undervisning ge återkoppling till lärare. Utgångspunkt tas i observationsinstrumentet Classroom Assessment Scoring System-Secondary (CLASS-S) (Pianta, Hamre, Hayes, Mintz \& LaParo, 2008), som fokuserar på i vilken grad klassrumsinteraktionen påverkar elevers motivation för att lära, deras engagemang och ansträngningar och deras lärande. Jämfört med lärare som under motsvarande tid (ett läsår) deltagit i "regular in-service training" höjde lärarna som följt programmet sina elevers resultat på statliga terminsprov med motsvarande $d=0,22$. Uppföljande observationer visade också att de förändrade interaktionsmönstren mellan lärare och elever med utgångspunkt i CLASS-S togs med till nya klasser följande skolår. En annan studie av Taylor och Tyler (2012) visade att matematiklärare, som återkommande under ett läsår fått återkoppling på sin undervisning utifrån observationsprotokollet Framework for Teaching (Danielson, 2007), höjde sina elevers resultat under flera på varandra följande läsår. Liknande resultat visar en studie av Stenberg och Sartain (2015). Wilkinson et al. (2016) visade i en studie med mellanstadielärare i language arts att forskares och lärares gemensamma analyser av videoinspelade klassrumssamtal och återkommande återkoppling till lärarna utifrån verktyget Argumentation Rating Tool (ART) bidrog till att utveckla samtalens undersökande, dialogiska kvaliteter och stärka elevers förmåga till självständig argumentation. En framgångsfaktor som flera av dessa studier lyfter och som vi vill ta fasta på i föreliggande studie är användningen av video. Genom att observera sin egen undervisning och genom att forskare och lärare får möjlighet att diskutera valda undervisningsförlopp blir det möjligt att koppla teoretiska definitioner av effektiv undervisning till empiriska situationer i det egna klassrummet och på så vis möjliggöra ett praktikbaserat lärande (Borko et al., 2017).

Flera av de verktyg som används i ovannämnda studier antas vara generiska med avseende på ämnen på så vis att lärare i olika ämnen kan använda dem med samma behållning. De empiriska resultaten varierar dock något mellan de olika observationsinstrumenten i detta avseende. PLATO, som utvecklats för language arts-undervisning, innehåller element som också visat sig användbara för observation av exempelvis matematikundervisning (Cohen, 2015). Men det finns anledning att anta att observationsinstrument med mer ämnesspecifik inriktning både har större potential att identifiera effektiva undervisningsstrategier (Hill \& 
Grossman, 2013) och utgör ett mera konstruktivt stöd för lärares undervisningsplanering. I en studie av Cohen, Schuldt, Brown och Grossman (2016) prövades PLATO som utgångspunkt för en två år lång utvecklingskurs för lärare i language arts. Lärare fick inte bara respons på sin undervisning utifrån PLATO utan fick också träna sig i att själva analysera sin undervisning utifrån de olika variablerna i observationsinstrumentet. Studien visar bland annat att den mängd tid lärarna får till förfogande får betydelse för deras utveckling liksom att lärarnas kapacitet att planera och strukturera sina lektioner hade stor betydelse för om de lyckades utveckla förmågan att ge strategiundervisning eller skapa ett produktivt diskussionsklimat i sina klasser (ibid.). Studien understryker framför allt att alla lärare kanske inte är betjänta av att följa samma slags professionsutvecklingsupplägg, men att PLATO är ett värdefullt verktyg för utvecklingspedagoger/ledare som vill observera och ge nyanserad återkoppling till sina kollegor.

\section{Föreliggande studie}

I den här studien prövar vi ett liknande upplägg med fyra högstadielärare i svenska. Försöket går ut på att genom observation och videoinspelning synliggöra lärarnas undervisning för dem själva med hjälp av PLATO. Därefter får de möjlighet att fördjupa sig i kriterierna för ett urval variabler för att därigenom kunna identifiera och verbalisera kritiska aspekter av undervisningen och ta detta som en utgångspunkt för utveckling. Forskningen som underbygger PLATO identifierar kritiska aspekter av effektiv language arts-undervisning på högstadienivå (se t ex Applebee, Langer, Nystrand \& Gamoran, 2003; Graham, 2006; Hillocks, 1995; McKeown, Beck \& Blake, 2009; Nystrand, 1997; Palincsar, 2003; Snow \& Biancarosa, 2003). Den lärarroll som PLATO premierar kan från ett svenskt perspektiv uppfattas som tämligen strukturerad. En lärare som får höga värden på PLATO-variabler är en lärare som exempelvis tydliggör de ämnesrelaterade förväntningarna på eleverna, som aktivt knyter samman innehållet i dagens lektion med det eleverna lärt tidigare, som ber eleverna utveckla och motivera sina resonemang, som låter dem analysera och bearbeta texter ingående och som ger rikhaltig återkoppling på deras prestationer med tydlig fokus på hur de kan utvecklas. Observera att denna lärarroll på flera sätt skiljer sig från det som i debattsammanhang ibland omnämns som en "traditionell” lärarroll. Den lärare som får höga värden på PLATO är inte med nödvändighet en lärare som håller långa genomgångar eller låter elever arbeta individuellt med lärobokstexter och uppgifter i arbetsböcker.

Det övergripande forskningsintresset i föreliggande studie handlar om huruvida observationer av videoinspelad undervisning och återkoppling till svensklärare baserat på utvalda variabler från PLATO kan användas för att stötta lärarna i att utveckla sin undervisning. Mer precist har följande frågor varit vägledande för analysen: 
1. Vilken förändring kan observeras i lärarnas undervisning, eller i deras tänkande om sin undervisning, efter att de observerats och fått återkoppling på undervisningen med utgångspunkt i PLATO?

2. Vilka problem brottas lärarna med för att åstadkomma förändring?

3. Vilka åtgärder/förändringar skulle kunna göra samarbetet mellan forskare och lärare mer framgångsrikt med avseende på målet om utvecklad undervisning?

Den teoretiska motiveringen för interventionens och analysens uppläggning hämtas delvis i Gibbons et al. (1994) beskrivning av nya former för kunskapsproduktion (så kallad Mode 2), som framför allt understryker behovet av att professionsrelevant kunskap utvecklas i en användarkontext med referens till verkliga, praktiska problem. Huruvida sådan kunskapsproduktion/-utveckling är framgångsrik eller inte avgörs inte huvudsakligen av inomvetenskapliga kriterier såsom logiska eller empiriska bevis för en hypotes, utan av om den nya kunskapen gör nytta och löser de verkliga, praktiska problemen. I användarkontexten är den senare sortens kunskap ofta av transdisciplinär natur, vilket innebär att den teoretiska utvecklingen i första hand sker i relation till den praktiska problemställningen och inte med en specifik ämnesdisciplin som referensram. I ett forskningsprojekt med fokus på praktikutveckling får dessa överväganden betydelse både för vad vi väljer att studera och på vilket sätt vi lägger upp studien. Den intressanta frågan här blir exempelvis inte om lärarna efter en viss typ av träning eller återkoppling på PLATO-variabler kan producera undervisning som får högre poäng på bedömningsskalorna, utan snarare om återkopplingen kan bidra till att fördjupa lärarnas professionella seende (Goodwin, 1994), det vill säga deras förmåga att urskilja professionellt relevanta och kritiska dimensioner på ett sätt som stöttar dem i planering och uppföljning av utvecklade undervisningsformer. Det vore i så fall ett forskningsresultat av specifikt praktikutvecklande karaktär och som lärarna sannolikt själva skulle uppleva och uppfatta den professionella relevansen av. Det skulle också vara en typ av forskningsresultat som gick i linje med ULF-projektets ambition om modellutveckling för samverkan mellan forskare och praktiker i skolan, i synnerhet den som sätter direkt fokus på undervisningsutveckling och ökad måluppfyllelse (se bl a Nordgren, Kristiansson, Liljekvist \& Bergh, 2019; Ryve, Hemmi \& Kornhall, 2016; SOU 2018:19).

Från tidigare forskning vet vi att långsiktig samverkan mellan forskare och lärare för successiv pedagogisk utveckling kan utgöra en fruktbar grund för utveckling (Bruce, Flynn \& Stagg-Peterson, 2011; Carlgren, 2011; Collins, Joseph \& Bielaczyc, 2004; Wilkinson et al., 2016). Att utveckla en gemensam förståelse för problemområdet ifråga är tidskrävande, men också nödvändigt för att deltagarna ska kunna utmana varandras uppfattningar och tolkningar (Avgitidou, 2009; Capobianco, 2007). I den här studien gör vi bruk av tidigare 
erfarenheter från liknande samarbetsprojekt, bland annat genom löpande gemensamma reflektioner över projektets utveckling (Capobianco, 2007).

\section{Metod och material}

\section{Design}

Studiens design lånar drag från aktionsforskning (Rönnerman, 2012) genom att professionellt utvecklingsarbete för lärarna kombineras med ett tvådelat forskningsperspektiv. Det ena har fokus på lärarnas individuella och gruppbaserade utvecklingsprocess. Det andra har fokus på den dubbla funktionaliteten i samarbetsmodellen, det vill säga samarbetet mellan lärare och forskare (på vilket sätt främjas forskarnas tillgång till relevanta data i en praktikutvecklande forskningssatsning av det här slaget; och i vilken grad stimuleras lärarnas utvecklingsprocess av den direkta tillgången till en forskningsbaserad modell av undervisningskvalitet och till det nära samarbetet med en forskargrupp?). Forskare och lärare diskuterar, planerar och dokumenterar en iscensättning av undervisning och analyserar därefter processen och planerar på nytt med sikte på att utveckla undervisningen. Studiens datainsamling sker därför delvis som en del av det gemensamma planerings- och analysarbetet och syftar specifikt till att följa och dokumentera den processen varför intervju och planeringssamtal sammanflätas med varandra. Designen bär också drag av interventionsstudie genom att forskare presenterar ett arbetsredskap (PLATO), som lärarna sedan använder sig av vid planering och genomförande av undervisningen. Forskarna har därefter observerat och gett återkoppling till lärarna med utgångspunkt i valda PLATOvariabler.

\section{Deltagare och material}

I studien medverkade inledningsvis fem högstadielärare i svenska från två skolor i två kommuner. En av lärarna valde att avsluta deltagandet under tiden på grund av förändrade arbetsuppgifter. Datainsamling med de återstående fyra lärarna pågick under drygt en termin. Det insamlade materialet utgörs av åtta videoinspelade svensklektioner, fyra ljudinspelningar av intervjuer med enskilda lärare samt fyra ljudinspelningar av gruppintervjuer.

\section{Professionsutveckling och datainsamling}

Lärarnas undervisning videofilmades vid två tillfällen, en gång i början och en gång i slutet av insamlingsperioden. PLATO användes för att koda lektionerna uppdelade i 15-minuterssegment. Båda forskarna kodade allt material oberoende av varandra och jämkade därefter sina resultat. Utifrån resultatet av kodningen, återkopplingen från forskarna liksom utifrån sina egna tankar om undervisningen valde lärarna individuellt två till fyra element som relaterade till områden de önskade utveckla i sin undervisning. Under utvecklingsarbetet som följde fick 
lärarna stöd av en av forskarna (Författare 2) i form av återkoppling på genomförd undervisning, korta föreläsningar och samtal om innebörden av de utvalda PLATO-elementen. En viktig del av dessa samtal handlade om hur de skalor som varje element är uppbyggt av skulle förstås och vad det kunde representeras av i praktisk undervisning. Lärare filmade också sig själva och varandra och träffades på respektive skola för att tillsammans reflektera kring PLATO-elementen och hur detta teoretiska innehåll kunde eller skulle omsättas till praktik. Efter att en deltagare hoppade av blev en lärare ensam i utvecklingsarbetet på sin skola och fick därför extra stöd av forskarna med filmning och reflektion över genomförd undervisning. Fyra enskilda lärarintervjuer genomfördes ca två månader efter starten. Gruppintervjuer och enskilda återkopplingssamtal genomfördes 1) efter första filmningen och kodningen; 2) under arbetsprocessen på respektive skola; och 3) vid ett avslutande möte där bland annat resultat från den andra filmningen och kodningen presenterades. Vid detta tillfälle fick lärarna dessutom feedback både skriftligt och muntligt.

\section{PLATO-elementen}

PLATO identifierar tolv separata variabler (PLATO-element) som var och en representerar specifika aspekter av undervisningen (modellering, återkoppling, strategiundervisning osv). Kodning görs på en fyrgradig skala, med tillhörande (elementspecifika) kvalitativa kriterier. Generellt gäller dock att ett undervisningsavsnitt kodas med låga värden (1-2) om nästan inga (1) eller begränsade belägg (2) för en viss undervisningsaspekt (innehållet i ett givet element) observeras. Höga värden (3-4) ges om det finns belägg med enstaka svagheter (3) eller återkommande, starka belägg (4). Explorativa och konfirmativa faktoranalyser har visat att de tolv elementen grupperar sig i fyra bredare domäner: Instructional Scaffolding, Disciplinary Demand, Representations and Use of Content, och Classroom Environment (se tabell 1) (Grossman et al., 2013).

Tabell 1. Domäner och element i PLATO.

\begin{tabular}{ll}
\hline Domän & Element \\
\hline Instructional Scaffolding & Modeling (MOD) \\
& Strategy Use and Instruction (SUI) \\
& Feedback (FDBK) \\
& Accommodations for Language Learning (ALL) \\
& Intellectual Challenge (IC) \\
Disciplinary Demand & Classroom Discourse (CD) \\
& Text-Based Instruction (TBI) \\
Representations and Use of Content & Representation of Content (ROC) \\
& Connections to Prior Knowledge (CPK) \\
& Purpose (PUR) \\
Classroom Environment & Behavior Management (BM) \\
& Time Management (TM) \\
\hline
\end{tabular}


I samband med den första återkopplingen fick lärarna bland dessa välja två, tre eller fyra element som de ville fördjupa sig i och utveckla i sin undervisning. Tabell 2 redogör för vilka element de fyra lärarna valde.

Tabell 2. Element som de fyra lärarna valde.

\begin{tabular}{ll}
\hline Lärare & Element \\
\hline Lärare 1 & Purpose (PUR) \\
& Strategy Use and Instruction (SUI) \\
Intellectual Challenge (IC) & Text-Based Instruction (TBI) \\
& Modeling (MOD) \\
Lärare 2 & Text-Based Instruction (TBI) \\
& Modeling (MOD) \\
Lärare 3 & Classroom Discourse (CD) \\
& Strategy Use and Instruction (SUI) \\
Lärare 4 & Intellectual Challenge (IC) \\
& Text-Based Instruction (TBI) \\
\hline
\end{tabular}

\section{Dataanalys}

De filmade lektionerna delades upp i 15-minuterssegment och kodades direkt från skärm med hjälp av PLATO. Kodningen har i första hand använts som underlag för återkoppling till lärarna, men den finns också med som ett underlag för att besvara studiens första forskningsfråga, som gäller observerade förändringar i lärarnas undervisning. Det bör dock understrykas att PLATO inte är ett verktyg utformat för att mäta förändring av undervisningskvalitet mellan enskilda lektioner, utan för att identifiera mönster i större datamaterial baserat på många lärares undervisning där varje lärare observeras vid flera lektionstillfällen. Eftersom PLATO-kodning dessutom påverkas i viss mån av undervisningsinnehåll (se Grossman et al., 2013), behöver kodning av enskilda lektioner ta hänsyn till undervisningsinnehåll, undervisningsmetoder och elevaktivitet. I studien hanterar vi dessa utmaningar genom att rikta uppmärksamheten inte i första hand mot den fyrgradiga skalan eller var lärarna hamnar på skalan under ett visst segment, utan mot kriterierna och hur de relaterar till det specifika undervisningsinnehållet samt hur lärarens planering kan skapa utrymme för höjd undervisningskvalitet i relation till kriterierna.

Samtliga enskilda intervjuer och gruppintervjuer har transkriberats med en förenklad transkriptionsmetod som grund för kvalitativ innehållsanalys. I analysen har vi sökt identifiera teman, det vill säga mönstrade (eng "patterned”) responser i relation till forskningsfrågorna, i enlighet med Braun och Clarkes (2006) beskrivning av tematisk analys. Detta analysarbete har lett fram till att vi i första hand fokuserat på upplevda förändringar hos lärarna antingen i sättet att undervisa eller i sättet att tänka om undervisningen, liksom på av lärarna upplevda problem med att åstadkomma förändring i form av undervisningsutveckling. Det sammanlagda materialet (filmer, intervjuer och intervjuanalyser) har därefter 
använts för att identifiera potentiella åtgärder för att utveckla samverkansmodellen.

\section{Resultat}

Undersökningens resultat presenteras nedan som svar på studiens tre forskningsfrågor.

\section{Förändrad undervisning eller förändrat tänkande om undervisning}

Den första forskningsfrågan gällde vilken förändring som kan observeras i lärarnas undervisning, eller i deras tänkande om sin undervisning, efter att de observerats och fått återkoppling på undervisningen med utgångspunkt i PLATO. Analysen visar att de fyra lärarna dragit nytta av återkopplingen de fick vid första observationstillfället och använt den för att utveckla sin undervisning. Bland utvecklingsområden som observeras, märks bland annat en fokusering av djupare förståelse i arbetet med texter, förtydligande av syftet med undervisningsaktiviteter samt högre förekomst av detaljerad och explicit strategiundervisning. Såväl PLATO-kodningen som lärarnas egna reflektioner efteråt indikerar att de specifika kriterierna för de utvalda PLATO-elementen synliggjort aspekter i undervisningen som lärarna uppfattat som relevanta och arbetat med.

Förtydligande av syfte med lektionsaktiviteter (Purpose i PLATO) är en dimension som alla fyra lärarna anammat. Även de som inte valt att jobba specifikt med detta element har ändå medvetet tagit in det i sin lektionsplanering. Vid första observationstillfället fick ingen av lärarna över nivå 2 på Purpose på den fyrgradiga bedömningsskalan på något av de 15-minuterssegment som lektionerna delades in i vid kodningen. Vid det andra observationstillfället hade de alla minst ett segment av lektionen där de nådde nivå 3. Nivå 3 på Purpose betyder att läraren dels formulerar ett specifikt och tydligt syfte med lektionens olika aktiviteter, dels förtydligar hur aktiviteterna bidrar till att utveckla elevernas färdigheter, exempelvis hur det utvecklar dem som läsare eller skribenter.

för nu har ju jag purpose och att det här att som vi pratade lite om förra gången, att "nej, det behöver inte vara så avancerat, jag behöver inte smälla upp centralt innehåll och kunskapskrav varje lektion”. Utan det kan räcka med att säga ”i dag gör vi det här för att ...”. Men också den, att avrunda med att återknyta till det. (Lärare 1, int 2)

Citatet visar hur lärarna urskiljer den kvalitativa skillnaden mellan nivå 2 och 3 på elementet Purpose genom att påpeka att den kvalitativa förstärkningen inte ligger i att hänvisa till kursplanens kunskapskrav och innehåll utan i att relatera klassrumsaktiviteter och uppgifter till ett högre syfte kopplat till elevernas kunskapsutveckling ("i dag gör vi det här för att”).

Ett annat område där tydlig effekt kan iakttas är bruket av explicit strategiundervisning. Två av lärarna i studien har haft detta som sin målsättning. 
En del av utmaningen med strategiundervisning, som lärare 4 påpekar i det första återkopplingssamtalet, handlar om ovanan att som en del av undervisningen explicit modellera tankeprocesser för elever.

Så här har vi inte traditionellt sett undervisat i Sverige. (...) Och nu finns det bevisligen ett behov utav det, det måste jag börja göra. Jag måste ha en explicit modellering av hur ska man tänka när man är elev och så ser man en text och så ska man läsa den här texten? Alltså hur gör man rent ...? Hur låter man när man läser den här texten? (Lärare 4, int 1)

Hon understryker också att explicit strategiundervisning inte är något som normalt förekommer tre dagar i veckan utan snarare ges i samband med en introduktion av något område ("som vanlig svensklärare så gör man inte det hela tiden, utan det är vid vissa tillfällen”). I återkopplingen till lärarna understryker vi som forskare emellertid, med hänvisning till PLATO-manualen, att förstärkning av elevernas förmåga att använda strategier, exempelvis för läsförståelse, även kan/bör bestå av referenser tillbaka till och uppmaning att använda tidigare presenterade strategier. Vid den uppföljande lektionen som observeras och filmas gör lärare 4 ett aktivt försök att explicitgöra strategier för läsning av faktatext. Resultatet bekräftas av PLATO-kodningen för elementet SUI som lektionen igenom ligger konsekvent högt (4, 4, 3 för de tre 15-minuterssegmenten). Vad kodningen fångar i lärare 4:s undervisning är ett metodiskt tydliggörande av att lektionen ska handla om strategier för läsförståelse. Hon benämner strategierna och klargör när och varför de är användbara. Dessutom modellerar hon strategierna i läsning av en text på smartboard och låter därefter eleverna pröva att själva använda dem på en ny text.

På det viset illustrerar datamaterialet hur återkopplingen till lärarna med utgångspunkt i PLATO-manualen kan synliggöra kvalitativt viktiga undervisningsdimensioner och bidra till utveckling på dessa områden. Samtidigt belyser innehållet i filmerna behovet av balans mellan olika undervisningsdimensioner och mellan olika arbetsmetoder för eleverna i planeringen av en lektion. Höga värden på SUI kombinerades nämligen med låga värden på IC och TBI. När lärares explicita strategiundervisning ställs i fokus riskerar alltså den intellektuella utmaningen för eleverna att utebli, helt enkelt därför att läraren, som står för strategiundervisningen, är den som tar en aktiv roll, medan eleverna får en mer passiv mottagarroll. På samma sätt är det läraren och inte eleverna som arbetar aktivt med texten i klassrummet. Detta kan utgöra ett steg i lärarens utvecklingsarbete, under vilket läraren som en del av träningen fokuserar på en dimension i taget. Det kan också handla om att en egenskap hos det teoretiska verktyget definierar undervisningsdimensioner som är svåra för lärare att kombinera i praktiken. Hur lärare kan ge större utrymme både för aktiv instruktion och för utmanande textbaserat arbete för eleverna utgör således nästa steg i utvecklingen av lektionsplaneringen. 
Av de förändringar som observerats i lärarnas undervisning liksom av deras sätt att benämna sin egen förståelseprocess konkluderar vi att det teoretiska verktyget varit både tillgängligt och skarpt ifråga om att precisera specifika kvaliteter och utvecklingsområden i undervisningen. Lärarna som deltagit uppger att de ser PLATO-variablerna som högst centrala och relevanta för utvecklingen av det pedagogiska ledarskapet i klassrummet ("Klockrent!"; "Görbra professionell vägledning”; "Super om man fått det här i lärarutbildningen”; ”Äntligen blir det så här explicit lärarkompetens"). Samtidigt framgår behovet av att kombinera en teoretisk fördjupning i PLATO-kriterierna med observation, filmning (som ger lärarna möjlighet att observera sig själva) och återkoppling. (”... men jag tror ändå det här när man tittar ... bara det här som ... Jag sa jag tror att jag modellerar väldigt mycket och verkligen fick se 'ja, men jag kan faktiskt modellera ännu mer’”, Lärare 3, grpsamt 2). Möjligheten att observera sig själv i arbetet blir således ett viktigt komplement för att som lärare synliggöra för sig själv sina egna utvecklingsområden. Det teoretiska verktyget tillsammans med observationen verkar möjliggöra en sammankoppling av teori och praktik där lärarna kan urskilja sig själva som professionella, med en professionell blick och ett professionellt språk för att benämna och analysera undervisningssituationen.

På det här viset understryker de deltagande lärarna att de utvecklat sin medvetenhet och förändrat några av sina tankesätt kring olika kvalitetsaspekter i undervisning. Dessa aspekter omfattar framför allt instruktion, uppläggning och planering av lektioner, men även det sätt på vilket de urskiljer elevers behov av pedagogiskt stöd långsiktigt och kortsiktigt.

\section{Upplevda hinder för att åstadkomma förändringar}

Den andra forskningsfrågan gällde vilka hinder lärarna upplever finns för att åstadkomma förändring. I analysen har vi identifierat tre typer av upplevda hinder: förståelse av PLATO-innehållet; svårigheten att omsätta teori till praktik; och organisatoriska hinder på arbetsplatsen.

Att förstå PLATO-variablernas skalor kräver både tid för reflexion och samtal med någon som redan kan manualen om det ska kunna bidra till ett förändrat tänkande eller en förändrad praktik. Det finns en risk att lärare alltför snabbt likställer PLATO-variabler med tidigare, närliggande kunskaper (t ex om modellering) och på det sättet förenklar eller missförstår innebörden i dem. Men det framgår också av datamaterialet att samtal och videoobservationer av den egna undervisningen kan hjälpa till med att blottlägga sådana missförstånd, eller åtminstone öppna för medvetenhet om att de kan existera. Citatet från lärare 3 ovan antyder det. Hon säger också: ”Ja, jag tog modellering för att jag tror att jag modellerar, och så tänkte jag att jag kanske inte ens gör det. Då var jag tvungen att kolla. Men jag tror att jag gör det i alla fall. Fast naturligtvis inte tillräckligt, det är klart man kan bli bättre.” (Lärare 3, grpsamt 2). Läraren berättar att hon valt att jobba med elementet Modeling (MOD) för att hon tyckte sig ha kunskap om dess innebörd sedan tidigare, men visar också att hon blir osäker på vad 
modellering innebär i PLATO-manualen. På det viset uppstår ett beroende av forskarna som expertis på PLATO-innehållet för att kunna utmana när lärare alltför snabbt "förstår” genom att översätta till redan känd kunskap.

Vidare framgår att manualens beskrivningar inte alltid så enkelt låter sig översättas till konkret undervisning, varför det finns ett behov av att kunna visa goda exempel på undervisning som uppfyller nivå 4 på de olika PLATOelementen. Både för att förstå kriteriernas innebörd i sig och för att kunna omsätta detta i egen handling behöver lärarna få möjlighet att observera konkreta realiseringar i autentiska klassrumssituationer. Eventuellt kan det också vara värdefullt med exempel som synliggör kvalitativa skillnader mellan de olika nivåerna på respektive element.

Även när lärarna upplever sig förstå innebörden i kriterierna menar de att det återstår en väsentlig utmaning i att planera undervisning som möjliggör en realisering av kriterierna i klassrummet. En av lärarna nämner som exempel sitt arbete med elementet Intellectual Challenge (IC). Hon uppger att hon ofta planerar för samtal med stort elevdeltagande och där hon inte nödvändigtvis vet var diskussionen kommer att leda. Detta ger dock inte alltid förutsättningar för att produktiva och utvecklande frågor till texterna ställs. Hur kan man skapa förutsättningar för samtal som både är öppna nog att kunna leda i olika riktningar men samtidigt förberedda nog för att garantera att elever utmanas på riktigt och inte slutar med att rekonstruera texttolkningar som läraren försett dem med? Här uttrycker samtliga deltagande lärare ett stort behov både av stöttning från dem som har kunskap om de didaktiska verktygen (i det här fallet forskarna) och av att få diskutera planeringsfrågor med kollegor och titta på varandras lektioner för att komma djupare i sin gemensamma förståelse av hur undervisningen kan utvecklas.

Den tredje typen av upplevda hinder knyter an till organisatoriska frågor som har att göra med lärares utrymme för gemensam reflexion och planering i arbetet. Detta handlar delvis om brist på utrymme i tjänsteplaneringen, det vill säga tid för planering och utveckling, men intervjuerna och samtalen med lärarna i studien understryker också behovet av resurser i organisationen för ett forskningsbaserat stöd för planering och utveckling. Kompetensutvecklingssatsningen som genomförs i studien kan utgöra exempel på en sådan resurs, men lärares behov av professionsutveckling löses inte med punktinsatser utan förutsätter mer långsiktigt hållbara strukturer för verksamhetsutveckling. Enbart tid för planering och utveckling riskerar, enligt lärarna, att sakna direkt styrning mot verkligt angelägna utvecklingsområden ("det är så lite som vi får ägna oss åt det som är professionsutvecklingen som pedagog") eller ätas upp av mer dagsakuta problem ("något elevärende" eller "mentorsskap"). Enbart tillgång till forskningsbaserade resurser utan tid och aktivt stöd är, som framgått ovan, heller inte tillräckligt. Innehållsrelaterat stöd (från kollegor, rektor, utvecklingspedagog och/eller klassrumsforskare) blir avgörande för ämnesfördjupning, genomförbarhet och kontinuitet. 


\section{Organisatoriskt-innehållsliga förstärkningar för utvecklad undervisning} Den tredje forskningsfrågan gällde vilka åtgärder eller förändringar som skulle kunna bidra till att göra samarbetet mellan forskare och lärare mer framgångsrikt med avseende på målet om utvecklad undervisning. Analysen visar att det finns behov av organisatoriskt-innehållsliga förstärkningar i framför allt tre avseenden. Det första gäller möjligheten till ett relevant kunskapsutbyte mellan universitet och skolhuvudman och handlar, som framgått ovan, om att möjliggöra riktad forskningsbaserad stöttning av det lokala förbättringsarbetet i skolan. En sådan stöttning kan bestå antingen i en specifik ämnesdidaktiskt utformad arbetsmodell för utvecklingsarbete (exempelvis en forskningscirkel med aktivt deltagande forskare) eller i ett ämnesinnehållsligt verktyg för undervisningsutveckling (som PLATO). Det andra gäller mottagarkompetens i skolorganisationen och handlar om behovet av en resurs som internt förankrar intentionerna i ett planerat förbättringsarbete och som ansvarar för implementering och successivt stöd till de lärare som deltar. Det tredje gäller tid för lärares deltagande: tid för möten, för reflexion och planering liksom tid för efterarbete av lektioner.

Forskningsbaserat utvecklingsarbete måste inte ledas lokalt av forskare, men av lärarnas utsagor framgår att forskarnas bidrag (analysverktyg, analyser, referens till annan forskning etc) upplevs som mycket värdefullt. Att förankra sådana resurser så att de förstås av skolans verksamma som relevanta är första steg, men här tyder studien på organisationsrelaterade svårigheter med att tillvarata även sådant som uppfattas som relevanta kunskaper och förankra dem lokalt. Ledningens inblick och deltagande i lärarnas utvecklingsarbete beskrivs som högst begränsat.

Det känns som att det är så i skolans värld. Rektorer kommer och går, de rullar förbi väldigt snabbt nu och de har så mycket de ska hålla (...). (Lärare 4, grpsamt 2)

Och jag driver ... Har ju haft Läslyftet. Det är fjärde gruppen jag kör nu och det har i alla fall varit fyra rektorer inblandade, men det finns aldrig någon som frågar om hur det går. (Lärare 2, grpsamt 2)

Men även om ledningens samtycke och formella stöttning är viktigt behöver en satsning av det här slaget i första hand en ämnesmässig och ämnesdidaktisk mottagarkompetens, som möjliggör ett långsiktigt utbyte av kunskap och erfarenheter mellan forskarsamhället och skolverksamheten. Detta handlar alltså om en organisatoriskt-innehållslig förstärkning i form dels av resurser som kan driva ämnesspecifikt inriktad professionsutveckling, dels av satsningar som riktar uppmärksamheten mot sådana förbättringar av undervisningen som leder till att eleverna utvecklar ämnesspecifika kunskaper. För svenskämnets del handlar det om insatser för en undervisning som i högre grad utvecklar eleverna som skribenter, läsare och talare.

Välutformade ämnesdidaktiska stödverktyg och ämnesdidaktiskt kunniga resurser gör dock liten nytta om lärare inte har tid för att ta del av och arbeta med undervisningsutveckling. Lärarna som deltagit i studien uttrycker återkommande 
tid som en begränsande resurs i sammanhanget: ”Det är hemskt att säga så i skolan, men det har gått åt tid till så mycket. Planeringen har skett hemma när man har ... ja, när barnen är lagda och så där på sistone” (Lärare 2, grpsamt 1). Samtliga uttrycker behov av ett större utrymme för att kunna arbeta tillsammans både med uttolkning av kvalitetskriterier för god undervisning och med analys av vad som sker i den egna undervisningen. Lärare 2 hänvisar till Läslyftet (alla fyra har deltagit i Läslyftet) som ett tillfälle då det fanns tid för den sortens reflexionsoch planeringsarbete.

Det jag saknar med Läslyftet, vi gick ju det förut, det är det här med det att faktiskt få reflektera vad man faktiskt håller på med, och ha tiden att titta och analysera och så där. $\mathrm{Nu}$ kan vi ta filmen och kolla hemma i lugn och ro. Men tänk dig [ohörbart] just efter lektionen eller tillsammans med någon och diskutera "vad håller vi på med egentligen?”. (Lärare 2, grpsamt 1)

Dessa tre aspekter (relevant utformat kunskapsutbyte mellan universitet och skolhuvudman; ämnesspecifik mottagarkompetens i skolorganisationen; och tid för lärare att koncentrera sig på systematiskt förbättringsarbete) utgör således exempel från studien på organisatoriskt-innehållsliga förstärkningar som skulle kunna bidra till ett långsiktigt hållbart och fruktbart samarbete för skolförbättring.

\section{Diskussion och slutsatser}

Den pedagogiska forskningens bidrag till höjd undervisningskvalitet definieras inte sällan genom studier som identifierar så kallad 'best practice' (Gambrell, Malloy \& Mazzoni, 2011). Sådana studier bygger som regel på kontrollerade experiment där särskilt tränade lärare eller instruktörer står för försöksundervisningen och där resultaten sedan jämförs med resultat från klassrum där det föregått "vanlig undervisning”. Undervisningsmetoder som i kontrollerade studier genererat goda resultat i form av en hög effekt på elevers kunskapsutveckling är emellertid inte alltid lätta för lärare att omsätta i klassrummet (Hacker \& Tenent, 2002). Variation i såväl lärares som elevers erfarenheter och förutsättningar leder inte sällan till att förväntade eller "bevisade" effekter uteblir eller åtminstone reduceras. Detta gäller förstås även när den bevisat framgångsrika undervisningen identifierats exempelvis genom komparativa observationer (se t ex Grossman et al., 2013). Därför är det viktigt att förstå villkoren för att lärare ska kunna tillgodogöra sig nya ämnesdidaktiska verktyg för att utveckla sin undervisning.

I den här studien har vi prövat i vad mån observationer av videoinspelad undervisning och återkoppling till lärarna utifrån ett forskningsbaserat observationsprotokoll (PLATO) kan användas för att stötta en sådan utveckling. Vår utgångspunkt har varit att ett kollaborativt arbete mellan lärare och forskare, som tar sin utgångspunkt i konkreta ämnesrelaterade utmaningar i det dagliga arbetet, 
inte behöver kringskära lärares professionella autonomi, utan att ett sådant samarbete tvärtom kan bidra med redskap som stärker lärares möjligheter att påverka och utveckla sin yrkesroll.

Studien visar att svensklärare som filmas och observeras och får återkoppling med utgångspunkt i PLATO kan dra nytta av både film och återkoppling för att utveckla kvaliteten på sin undervisning, något som bekräftar tidigare forskningsresultat dels gällande värdet av PLATO som professionsutvecklingsverktyg (Cohen et al., 2016), dels gällande betydelsen av videoinspelad undervisning som utgångspunkt för utvecklingsinriktad dialog mellan forskare och lärare (Borko et al., 2017). Genom att bearbeta återkopplingen tillsammans med kollegor och med utgångspunkt i det planera och genomföra ny undervisning demonstrerar lärarna i den här studien att forskningsbaserade kvalitetsdimensioner kan byggas in i ett kollaborativt utvecklingsarbete och inte bara påverka deras handlingar utan också höja deras medvetenhet om den egna undervisningens möjligheter och begränsningar.

Av studien framgår också att det är ett krävande arbete för lärarna att sätta sig in i det teoretiska verktyget och omsätta det i konkret undervisning. Stöttning från forskaren med uttolkning av och återkoppling utifrån PLATO ses som nödvändig. Därutöver framgår att schemautrymme både för teoretisk fördjupning och för konkret planeringsarbete tillsammans med kollegorna är en avgörande faktor (jfr Nordgren et al., 2019).

Till de konkreta behov av organisatoriska förstärkningar som analysen pekar på hör även mottagarkompetens på skolan eller i skolorganisationen som internt kan fånga upp och förankra ett innehållsspecifikt utvecklingsarbete också i ett långsiktigt perspektiv. Detta behov diskuteras nedan med utgångspunkt i resultaten på såväl forskningsfråga två som forskningsfråga tre.

Ett flertal tidigare studier har visat att observationsprotokoll som utformats för storskaliga observationer av naturligt förekommande undervisning också kan användas för att ge återkoppling till lärare på genomförd undervisning och på det viset bidra till ämnesspecifik professionsutveckling (Allen et al., 2011; Crosson et al., 2006; Taylor \& Tyler, 2012). Cohen et al. (2016) visade att PLATO specifikt fungerade väl för language arts-lärare, men att hur mycket stöd lärare behövde varierade liksom att effekterna av stödet berodde bland annat på lärarnas kapacitet att planera och strukturera lektioner.

Den här studien antyder alltså att ett liknande upplägg och didaktiskt innehåll kan vara fruktbart även för svensklärare, men att det finns behov av ett lokalt baserat och ämneskompetent stöd både för att stötta lärares omsättning av teori till praktik och för att hålla liv i utvecklingsarbetet över tid om satsningen ska fungera. Föreliggande studie är småskalig och resultaten baseras på analyser där ett fåtal lärare vid två olika skolor följt en kortare variant av en tänkt professionssatsning. För att ta fram tillförlitligare kunskap om i vilken mån observationer och videoinspelning av undervisning följt av återkoppling till lärarna kan bidra till 
utvecklad undervisningskvalitet skulle modellen behöva prövas i större skala. För att dessutom få veta mer om behoven av organisatoriskt stöd och utveckling, och för att möjliggöra en större och mera varaktig effekt av interventionen, skulle försöksarbetet utsträckas till fler ämnesdidaktiskt inriktade träffar över längre tid (jfr Garet, Porter, Desimone, Birman \& Yoon, 2001).

Den genomförda pilotstudien väcker emellertid en rad frågor, som vi bedömer skulle behöva undersökas närmare i en sådan utvidgad studie. Lärarnas egen analys av sin undervisning via inspelningarna framstår som värdefull. I studien har vi dock inte gett deltagarna specifika verktyg, utöver PLATO-innehållet, för att göra sådana analyser. Inledningsvis berörde vi frågan om i vilken grad förbättringsarbetet ägs av lärarna själva och drivs lokalt av dem snarare än från universitetet av forskare. Resultaten antyder att det här fortfarande i hög grad är en forskardriven insats och att den ämneskompetenta mottagarinstans som avses ovan har en potentiellt viktig roll att spela. Lärarna har heller inte på något systematiskt sätt utnyttjat varandra som resurs, något som också signalerar behovet av en utvecklingsinriktad ledningsfunktion. I en utvidgad försöksverksamhet där fler lärargrupper involveras blir sådana komponenter särskilt viktiga. En tänkbar utveckling av samarbetsmodellen skulle kunna vara att som utvecklingsstöd nyttja de regionala nätverken av kommunalt baserade läs- och skrivutvecklare. Det skulle också kunna bidra till att stötta ett regionalt samarbete kring ämnesspecifikt utvecklingsfokus på mellanledarnivå, något som ligger i linje med ambitionerna i ULF-projektet.

I studien av Cohen et al. (2016) väljer forskarna vilka PLATO-variabler som lärarna ska arbeta med. I den här studien valde lärarna själva variabler efter att vi observerat och kodat deras första lektion. Att få välja bidrar eventuellt till lärarnas motivation och kan också uppfattas som mer verkningsfullt eftersom de får lov att bearbeta aspekter av undervisningen som de själva upplever behöver utvecklas. $\AA$ andra sidan försvåras det gemensamma planerings- och utvärderingsarbetet. Delad kunskap om det didaktiska innehållet är en viktig faktor för att gruppen ska kunna utmana varandras tolkningar och genomförande av undervisning (jfr Avgitidou, 2009). Utan det blir professionsutvecklingen i högre grad ett individuellt projekt än ett kollegialt projekt.

Till sist är det också angeläget att beröra frågan om förbättringsarbetets långsiktiga hållbarhet. Den övergripande ansatsen i försöksverksamheten ULF handlar om att pröva ut modeller för ett långsiktigt hållbart samarbete om praktikutvecklande forskning i skolan. Till de redan kända faktorerna för att gynna långsiktighet (se t ex SOU 2018:19, s. 106ff) har den här studien lyft fram behovet av en mottagarkompetens i skolorganisationen för forskningsbaserat förbättringsarbete. Men det är också angeläget att peka på det engagemang i uppgiften som lärarna själva uttrycker därför att de ser en direkt konsekvens av samarbetet för kvaliteten på deras undervisning. Det är alltså inte enbart så att samarbetet blir intressant därför att det handlar om frågor som är av ömsesidigt intresse eller som tar sin utgångspunkt i lärarnas behov, utan också därför att själva 
forskningsprocessen inkluderar ett pågående utvecklingsarbete, som lärarna upplever bidrar till förbättring i praktiken. Ytterligare en ingrediens i långsiktig hållbarhet, vid sidan om gemensamt formulerade syften (ibid.), handlar därför om respekt för det faktum att parterna kan ha delvis olika intressen eller syften med samarbetet, men att dessa i sin tur kan bidra ömsesidigt till varandras förverkligande.

\section{Om författarna}

Michael Tengberg är professor i pedagogiskt arbete vid Karlstads universitet. Hans forskning handlar i första hand om elevers läsning och läsundervisningen i skolan.

Institutionell tillhörighet: Institutionen för pedagogiska studier, Karlstads universitet, Universitetsgatan 2, 65188 Karlstad, Sverige.

E-mail: michael.tengberg@kau.se

Marie Wejrum är doktorand i pedagogiskt arbete och universitetsadjunkt i svenska språket vid Karlstads universitet. Hennes forskningsintresse är främst elevers läsförståelse och skolans läsundervisning.

Institutionell tillhörighet: Institutionen för pedagogiska studier, Karlstads universitet, Universitetsgatan 2, 65188 Karlstad, Sverige.

E-mail: marie.wejrum@kau.se

\section{Referenser}

Allen, J. P., Pianta, R. C., Gregory, A., Mikami, A. Y. \& Lun, J. (2011). An interaction-based approach to enhancing secondary school instruction and student achievement. Science, 333, 1034-1037.

Applebee A. N., Langer J. L., Nystrand M. \& Gamoran A. (2003). Discussion-based approaches to developing understanding: Classroom instruction and student performance in middle and high school English. American Educational Research Journal, 40, 685730.

Avgitidou, S. (2009). Participation, roles and processes in a collaborative action research project: A reflexive account of the facilitator. Educational Action Research, 17, 585-600.

Bell, C. A., Dobbelaer, M. J., Klette, K. \& Visscher, A. (2018). Qualities of classroom observation systems. School Effectiveness and School Improvement, 30(1), 3-29.

Borko, H., Carlson, J., Mangram, C., Anderson, R., Fong, A., Million, S., ... Villa, A. M. (2017). The role of video-based discussion in model for preparing professional development leaders. International Journal of STEM Education, 4(1), 1-15.

Braun, V. \& Clarke, V. (2006). Using thematic analysis in psychology. Qualitative Research in Psychology, 3(2), 77-101.

Bruce, C. D., Flynn, T. \& Stagg-Peterson, S. (2011). Examining what we mean by collaboration in collaborative action research: a cross-case analysis. Educational Action Research, 19(4), 433-452. 
Bryk, A., Sebring, P. B., Allensworth, E., Luppescu, S. \& Easton, J. (2010). Organizing schools for improvement: Lessons from Chicago. Chicago, IL: University of Chicago Press.

Capobianco, B. M. (2007). Science teachers’ attempts at integrating feminist pedagogy through collaborative action research. Journal of Research in Science Teaching, 44(1), $1-32$.

Carlgren, I. (2011). Forskning ja, men i vilket syfte och om vad? Om avsaknaden och behovet av en 'klinisk' mellanrumsforskning. Forskning om lärande och undervisning, 5, 64-79.

Cohen, J. (2015). Challenges in identifying high leverage practices. Teachers College Record, 117(7), 1-41.

Cohen, J. \& Grossman, P. (2016). Respecting complexity and measures of teaching: Keeping students and schools in focus. Teaching and Teacher Education, 55, 308-317.

Cohen, J., Schuldt, L. C., Brown, L. \& Grossman, P. (2016). Leveraging observation tools for instructional improvement: Exploring variability in uptake of ambitious instructional practices. Teachers College Record, 118(11), 1-36.

Colbert, J., Brown, R., Choi, S. \& Thomas, S. (2008). An investigation of the impacts of teacher-driven professional development on pedagogy and student learning. Teacher Education Quarterly, 35(2), 135-154.

Collins, A., Joseph, D. \& Bielaczyc, K. (2004). Design research: Theoretical and methodological issues. Journal of the Learning Sciences, 13(1), 15-42.

Crosson, A. C., Boston, M., Levison, A., Matsumura, L. C., Resnick, L. B., Wolf, M. K. \& Junker, B. W. (2006). Beyond summative evaluation: The instructional quality assessment as a professional development tool. CSE Report 691, National Center for Research on Evaluation, Standards and Student Testing (CRESST). Los Angeles, CA: University of Los Angeles.

Danielson, C. (2007). Enhancing professional practice. A framework for teaching. Alexandria, VA: Association for Supervision and Curriculum Development.

Gambrell, L. B., Malloy, J. A. \& Mazzoni, S. A. (2011). Evidence-based best practices in comprehensive literacy instruction. I L. M. Morrow \& L. B. Gambrell (red.), Best Practices in Literacy Instruction (4 ${ }^{\text {th }}$ ed.) (s. 11-37). New York, NY: The Guilford Press.

Garet, M., Porter, A., Desimone, L., Birman, B. \& Yoon, K. (2001). What makes professional development effective? Analysis of a national sample of teachers. American Education Research Journal, 38(4), 915-945.

Gibbons, M., Limoges, C., Nowotny, H., Schwartzman, S., Scott, P. \& Trow, M. (1994). The new production of knowledge. London: SAGE.

Goodwin, C. (1994). Professional vision. American Anthropologist, 96(3), 606-633.

Gore, J. M., Lloyd, A., Smith, M., Bowe, J., Ellis, H. \& Lubans, D. (2017). Effects of professional development on the quality of teaching: Results from a randomised controlled trial of Quality Teaching Rounds. Teaching and Teacher Education, 68, 99-113.

Graham, S. (2006). Strategy instruction and the teaching of writing: A meta-analysis. I C. A. MacArthur, S. Graham \& J. Fitzgerald (red.), Handbook of Writing Research (s. 187207). New York: Guilford.

Grossman, P., Cohen, J., Ronfeldt, M. \& Brown, L. (2014). The test matters: The relationship between classroom observation scores and teacher value-added on multiple types of assessment. Educational Researcher, 43(6), 293-303.

Grossman, P., Loeb, S., Cohen, J. \& Wyckoff, J. (2013). Measure for measure: The relationship between measures of instructional practice in middle school English language arts and teachers' value-added scores. American Journal of Education, 119(3), 445-470. 
Hacker, D. J. \& Tenent, A. (2002). Implementing reciprocal teaching in the classroom: Overcoming obstacles and making modifications. Journal of Educational Psychology, 94(4), 699-718.

Haertel, B. E. H. (2013). Reliability and validity of inferences about teachers based on student test scores. William H. Angoff memorial lecture series. Educational Testing Service.

Hattie, J. (2009). Visible learning: A synthesis of over 800 meta-analyses relating to achievement. London: Routledge.

Hill, H. \& Grossman, P. (2013). Learning from teacher observations: Challenges and opportunities posed by new teacher evaluation systems. Harvard Educational Review, 83(2), 371-384.

Hillocks, G. (1995). Teaching writing as reflective process. New York: Teachers College Press.

Kane, T. J. \& Staiger, D. O. (2012). Gathering feedback for teaching: Combining high-quality observations with student surveys and achievement gains. Research paper, MET Project, Bill \& Melinda Gates Foundation.

Klette, K., Blikstad-Balas, M. \& Roe, A. (2017). Linking Instruction and Student Achievement. A research design for a new generation of classroom studies. Acta Didactica Norge, 11(3), Art. 10.

McKeown, M., Beck, I. \& Blake, R. (2009). Rethinking reading comprehension instruction: A comparison of instruction for strategies and content approaches. Reading Research Quarterly, 44(3), 218-253.

Nordgren, K., Kristiansson, M., Liljekvist, Y. \& Bergh, D. (2019). Lärares planering och efterarbete av lektioner. Infrastrukturer för kollegialt samarbete och forskningssamverkan. Rapport 2019:11. Karlstad: Karlstad University Studies.

Nystrand. M. (with Gamoran, A., Kachur, R. \& Prendergast, C.) (1997). Opening dialogue: Understanding the dynamics of language and learning in the English classroom. New York: Teachers College Press.

Palincsar, A. M. (2003). Collaborative approaches to comprehension instruction. I A. P. Sweet \& C. E. Snow (red.), Rethinking reading comprehension (s. 99-114). New York, NY: Guilford.

Pianta, R. C., Hamre, B. K., Hayes, N., Mintz, S. \& LaParo, K. M. (2008). Classroom Assessment Scoring System-Secondary (CLASS-S). Charlottesville, VA: University of Virginia.

Ryve, A., Hemmi, K. \& Kornhall, P. (2016). Skola på vetenskaplig grund. Stockholm: Natur och Kultur.

Rönnerman, K. (2012). Aktionsforskning i praktiken: förskola och skola på vetenskaplig grund. Lund: Studentlitteratur.

Snow, C. E. \& Biancarosa, G. (2003). Adolescent literacy and the achievement gap: What do we know and where do we go from here? New York: Carnegie Corporation.

SOU 2018:19. Forska tillsammans - samverkan för lärande och förbättring. Betänkande av Utredningen om praktiknära skolforskning i samverkan. Stockholm:

Utbildningsdepartementet. https://www.regeringen.se/4933fc/contentassets/1e0e6381c554497ab51eeeb13d36b1ce/so u-2018_19.pdf

Sparks, D. (2004). The looming danger of a two-tiered professional development system. Phi Delta Kappan, 86(4), 304-308.

Steinberg, M. P. \& Sartain, L. (2015). Does teacher evaluation improve school performance? Experimental evidence from Chicago's Excellence in Teaching Project. Education Finance and Policy, 10(4), 535-572. 
Taylor, E. S. \& Tyler, J. H. (2012). The Effect of Evaluation on Teacher Performance. The American Economic Review, 102(7), 3628-3651.

Tengberg, M. (2019). Textanvändning och texttolkning i svenskundervisningen på högstadiet. Nordic Journal of Literacy Research, 5(1), 18-37.

Utbildningsdepartementet (2017). Uppdrag om försöksverksamhet med praktiknära forskning. Regeringsbeslut U2015/03573/UH, U2017/01129/UH 2017-03-09. Stockholm:

Utbildningsdepartementet.

https://www.regeringen.se/49ba4e/contentassets/ed0440fcafde445ca40cb470c3eed7fc/up pdrag-om-forsoksverksamhet-med-praktiknara-forskning.pdf

Walls, M. \& Nilsson, J. (2019). Skolutveckling urholkar lärares autonomi. Skola \& Samhälle [S.O.S.] Hämtad 2019-05-23 från https://www.skolaochsamhalle.se/flode/skolpolitik/michael-walls-och-jan-nilssonskolutveckling-urholkar-larares-autonomi/

Wilkinson, I. A. G., Reznitskaya, A., Bourdage, K., Oyler, J., Glina, M., Drewry, R., Kim, M.-Y. \& Nelson, K. (2016). Toward a more dialogic pedagogy: changing teachers' beliefs and practices through professional development in language arts classrooms. Language and Education, 31(1), 65-82. 